\title{
Can intensive silviculture contribute to sustainable forest management in northern ecosystems?
}

\author{
by R.A. Lautenschlager ${ }^{1}$
}

\begin{abstract}
In the midst of changing social, ecological, and technical realities, interest in intensive silviculture has resurfaced. Intensive silviculture could build on previous silvicultural approaches, simply intensifying use of the treatments or treatment combinations identified in this paper to increase timber production, but the costs and benefits for specific treatments or treatment combinations remains unclear. Or intensive silviculture could be based on new thinking, refocusing so that increasing amounts of fibre are produced on dramatically younger, agricultural-like fibre farms located in areas that have the longest possible growing season. If fibre farming, using either natural or artificial regeneration, becomes increasingly more important, emphasis will start to be placed as much on equipment and integration of fibre production with manufacturer needs as on previously standard silvicultural treatments. Regardless of the form taken, some reject the suggested advantages of intensive silviculture, recommending instead a knowledge-intensive integrated approach or a combination of approaches. Although integrated landscape management is increasingly becoming the foundation for forest management, silvicultural direction remains unclear. Silviculturalists and managers will reap rewards by increasing silvicultural intensity only if their plans are scientifically based and socially acceptable. Before reasonable silvicultural directions can be developed, responsible parties need to frame and agree on the most realistic approaches that address both social and ecological concerns. Calls for increased silvicultural intensity are based on the recognition that status quo management could result in increasing fibre imports to satisfy local producer and consumer needs. Still, much of our naturally less productive northern forested land base seems far from ripe for increasing silvicultural intensity dramatically. Even so, those who continue status quo forest management solely may become increasingly less competitive. In an increasingly interdependent world market-based economy it is unclear whether intensive silviculture in northern ecosystems can be competitive with production in other parts of the world.
\end{abstract}

Key words: economics, fibre production, forest management, integrated landscape management, intensive silviculture, social concerns, sustainable forest management

L'intérêt pour la sylviculture intensive semble refaire surface alors que les réalitées sociales, écologiques et techniques changent. La sylviculture intensive pourrait s'appuyer sur les approches sylviculturals passées en intensifiant simplement l'usage des traitements ou des combinaisons de traitements identifiés dans ce papier pour accroître la production des bois. Cependant, le coût de traitements spécifiques ou de combinaisons de traitements restent incertains. La sylviculture intensive pourrait aussi se baser sur une nouvelle façon de penser, se concentrant sur une augmentation de la production de fibre sur des parcelles beaucoup plus jeunes, dans des fermes à fibre de type agricole, situées dans les régions qui ont les plus longues saisons de croissance. Si la culture de la fibre, utilisant la régénération naturelle ou non, devient de plus en plus importante, l'équipement et l'intégration de la production de fibre avec les besoins des manufacturiers deviendront aussi importants que les traitements agricoles standards. Quelle que soit sa forme, certains rejettent les avantages supposées de la sylviculture intensive, recommandant plutôt une approche de la gestion des resources naturelles intégrée et basée sur connaissance intensive, ou une combinaison d'approches. Même si l'aménagement intégré du paysage devient progressivement la base de l'aménagement forestier, la direction que prend la sylviculture reste incertaine. Les sylviculteurs et les aménageurs ne récolteront les fruits d'une augmentation d'intensité de la sylviculture seulement si leurs plans sont scientifiquement fondés et socialement acceptables. Avant que des directions de sylvicultures ne soient développées, il faut que les parties responsables s'accordent sur une définition des approches les plus réalistes qui tiennent en compte les problèmes sociaux et écologiques. Les appels à une augmentation de l'intensité sylviculturale sont basés sur la reconnaissance qu'un status quo de l'aménagement actuel pourrait résulter dans l'augmentation des importations de fibre pour satisfaire le producteur local et les besoins du consommateur. Par ailleurs, la majeure partie des forêts du nord, moins productives, semblent loin d'être prêtes à une augmentation considérable de l'intensité sylvicultural. Quoiqu'il en soit, ceux qui continuent à pratiquer seulement un status quo de l'aménagement forestier deviendront de moins en moins compétitifs. Dans une économie de marché de plus en plus interdépendante à l'echelle mondiale, il n'est pas certain que la sylviculture dans les écosystèmes du nord puisse rester compétitive face à la production dans d'autres parties du monde.

\section{Introduction}

In 1999, Canada's Senate subcommittee report on the boreal forest (Taylor 1999) and Ontario's Living Legacy strategy (OMNR 1999a) catapulted intensive silviculture back into forest management prominence in Canada. The Senate report recommended $20 \%$ of the boreal forest be man-

\footnotetext{
${ }^{1}$ Ontario Ministry of Natural Resources, Ontario Forest Research Institute, 1235 Queen Street East, Sault Ste. Marie, Ontario P6A 2E5. Email; r.a.lautenschlager@mnr.gov.on.ca
}

aged intensively for timber and fibre production (Taylor 1999). Ontario's Living Legacy and the associated Forest Accord (OMNR 1999b) suggested that intensive silviculture (called intensive forest management) be practised in designated zones to maintain existing wood flows and costs for mills, increase the quanti-

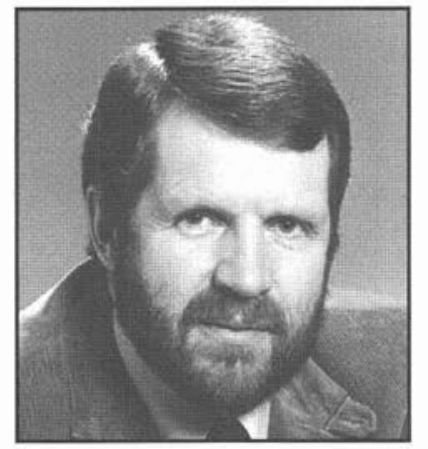


ty and quality of the wood fibre produced, and potentially increase the future supply of fibre from a land base where protected areas are being increased while areas for forestry are being reduced.

Forest Accord commitments to Ontario's forestry industry included that "there would be no net increase in the cost of wood delivered to the mill and there would be no long term reduction in the supply of fibre necessary for processing ... as the result of the establishment of new protected areas" (OMNR 1999b). In addition, all parties agreed to "Develop an Ontario forest science partnership in order to:

- develop and test a range of intensive (silvicultural) practices;

- assess the impacts of intensive (silviculture) on ... forest (fibre production);

- assess the environmental impacts of intensive (silviculture); and

- direct science activities in support of Ontario's forest management planning requirements under the Timber Class Environmental Assessment and Crown Forest Sustainability Act."

Following the signing of the Forest Accord the Ontario Ministry of Natural Resources (OMNR), the Canadian Forest Service (CFS), and Ontario's forest industry began to develop a coordinated response to address these and related commitments. This overview, part of that response, examines: 1 ) the foundations of intensive silviculture; 2) the increasing demands for wood fibre and associated increases in silvicultural intensity; 3 ) the role of silviculture within the timber management cycle; 4) costs, benefits, and concerns associated with specific silvicultural treatments; and 5) the sustainability of intensive silviculture. A more detailed analysis is being prepared.

\section{Foundations of silviculture}

Major components of modern forestry include policy (sociological and political), management (planning, economic analysis, harvest scheduling, and administration), and silviculture (Smith et al. 1997). Silviculture (literally tree or forest culture) is the art and science of producing and caring for (tending) stands, forests, and landscapes to meet present and future needs of landowners and society (a synthesis of definitions from Hartig 1795, Baker 1950, CFS 1995, Smith et al. 1997, Helms 1998). Although silviculture may be used to produce or maintain individuals or stands of specific tree species, as well as mosaics of successional stages, forest types, and the wildlife habitat associated with each stage (Lautenschlager $e t$ al. 1995, Smith et al. 1997), it is most commonly used to guide natural processes so that merchantable volume is produced more quickly than it would be produced naturally (Smith et al. 1997). Extensive and intensive (called incremental in British Columbia - CFS 1995) are the silvicultural extremes, and although Duerr (1960) provided economically based definitions, these extremes are more commonly defined as:

Extensive: Silviculture that relies on natural processes with minimal human input, i.e., low operating and investment costs/unit area (SAF 1983).

Intensive : Silviculture that involves natural and/or artificial processes that contribute to forest development and growth augmented (depending on the degree of intensity) by increasing inputs of labour and capital (intended to increase volume and/or quality/unit area) (SAF 1983). Lautenschlager (1999a) defined intensive silviculture as management that, in addition to maintaining specific tree species or forest cover types, can increase the volume, value, or both of a variety of future forest components within a sustainable management context.

In practice, silviculture is a continuum from extensive to intensive. The degree and appropriateness of silvicultural intensity along that continuum varies with ownership, management objectives, proximity to mills and/or transport centres, accessibility to management unit(s), markets, and site quality (Smith et al. 1997).

\section{Increasing Silvicultural Intensity}

Globally, silvicultural intensity has increased slowly over the last 50 years and more rapidly during the last 20 years (Reed et al. 1978, Wernick et al. 1998). These increases, however, have been greater in some countries or regions and minimal or nonexistent in others. Although there are exceptions based on historical uses and economic need, the degree of silvicultural intensity being practised anywhere is as flavoured by local philosophy and government agenda as by the differences in productivity noted by Sedjo et al. (1998).

In northern North America, silvicultural intensity has changed through time, gradually shifting from non-existent 100 years ago to extensive (some protection from insects and wildfires) 70 years ago, to increasingly more intensive 50 to 30 years ago on both industrial and public lands (Widner 1968, Seymour and Hunter 1992, Perry 1998, Taylor 1999). These changes reflect changing conditions: management objectives, remaining untended forest, labour, technology, fibre requirements, and economics.

Historically, in Canada, standard practice involved little or no forest management (Reed et al. 1978), although varying degrees of silvicultural intensity have been practised since the early 1900s (Reed et al. 1978, Rowe 1992, Taylor 1999, Armson et al. 2000). Major regeneration efforts in Canada began only after World War II (Armson et al. 2000). The seriousness of those efforts is demonstrated by the associated development of a variety of physiographically based forest site classification systems [see The Forestry Chronicle 68(1) - 1992)]. That development followed the realization that continued use of natural production in Canada was unlikely to be sustainable and that people would have to help reforest previously forested lands (Corns 1992). Reed et al. (1978) presented guidelines for increasing silvicultural intensity in Canada 20 years ago; however, by the early 1990 s only $20 \%$ of managed Canadian forests were site prepared after harvesting (CCFM 2000), suggesting that roughly $80 \%$ continued to be managed extensively.

Classification systems that have been developed and refined were designed in part to help identify where silvicultural treatments could be integrated into the larger natural resource management picture (Carmean 1996). Once fully developed, these systems, in concert with other hierarchical or bio-physical approaches, should serve as the foundation for a variety of land-management decisions. These decisions will include placing all natural resource management, including silvicultural efforts, into context with a variety of other land uses integrated landscape management.

Although Benson (1988) and Oliver (1999) outlined the benefits of extensive silviculture in northern forested ecosystems, silvicultural intensity has gradually increased in these ecosystems during the last 30 years (Seymour and Hunter 1992, Perry 
1998). By the 1970s, intensive silvicultural approaches (site preparation, planting, and aerial herbicide conifer release) and programs (prime site and hybrid poplar management) were well underway or were being developed (genetic improvement). Reed et al. (1978) and Armson (1979) outlined incentives for intensive silviculture across Canada and Ontario, respectively. Others, representing most Canadian provinces and territories, also proposed increasing silvicultural intensity soon after this time [see The Forestry Chronicle 68(1) 1992]. Over the last few years, there have been new calls for increasing silvicultural intensity across Canada (McColm 1986; Binkley 1997; Dietz 1997; Kryzanowski 1998; Lautenschlager 1999a; OMNR 1999a,b; Taylor 1999).

Historically, enthusiasm for increasing silvicultural intensity has been cyclic, and critics have been and continue to be sceptical. Oliver (1999), echoing Benson's (1988) arguments, outlined the long-term benefits of integrated forest management. Brown et al. (1999) suggested that the constantly changing mix of ecological, economic, and social constraints and opportunities associated with forested ecosystems makes longer-term decisions difficult and silvicultural investments risky. Brown et al. (1999) concluded that managerial expertise and manipulations of naturally occurring processes, rather than more intensive cultural inputs, are keys to economically and ecologically realistic forest management decisions. Smith et al. (1997) advised that "the most astute silviculture is the kind conducted at low intensity in which much is accomplished with a limited amount of treatment." Lautenschlager (1998a, 1999b) and Messier and Kneeshaw (1999) call for socially/ecologically based integrated management.

Boyle (1999) and others have identified general ecological and social benefits associated with intensive silviculture. More specifically, Seymour and McCormack (1989), Binkley (1997), and Sedjo and Botkin (1997) have argued that increasing the amount of intensively managed land will reduce the amount of land where silviculture will be practised and hence save associated ecosystems from potential managementrelated problems. Wernick et al. (1998) examined consumers, millers (producers), and foresters, and the potential of changes or improvements that each of these groups could make (e.g., millers could substitute materials or improve their use of existing materials) to conserve the world's forests. They concluded that changes in forest production (through silviculture) offered the greatest potential for conserving forests and noted (as did Seymour and McCormack 1989, Binkley 1997, and Sedjo 1999) that by growing trees faster, foresters could produce more on dramatically less land. Seymour and McCormack (1989) argued that, depending on the silvicultural options used, one third or less of the forest being used today would be needed to maintain the production of Maine's forest lands. Binkley (1997) argued that only $40 \%$ of the land now used for forest fibre production in British Columbia (18\% of the province's total productive forest area) would be needed to meet fibre requirements if a system of zoning and intensively managed plantations was implemented.

Although production increases of eight or more times those presently obtained in Canada from intensively versus extensively managed forests have been suggested (Taylor 1999), production potential of intensively managed plantations varies greatly among forest types around the world (Sedjo et al. 1998). Because of its relatively short growing season ( 4 months) and soil nutrient (particularly nitrogen) limitations (Messier and Kneeshaw 1999), production potential of boreal forests is commonly considered to be limited (Benson 1988, Sedjo $e t$ al. 1998). Seymour and Hunter (1992), however, asserted that volume extracted from intensively managed stands in boreal spruce-fir forests on 30 to 50 year rotations are expected to be two to five times more $\left(6-10 \mathrm{~m}^{3} / \mathrm{ha} / \mathrm{yr}\right)$ than those from unmanaged stands. Similar results have been reported by Seymour and McCormack (1989), McCullough (1999), and Wagner et al. (1999).

Thus, if successful, increased silvicultural intensity could help avoid potential roundwood shortfalls, while reducing the land area required to produce that fibre. However, management-related gains on the productive but less fertile colder or wetter sites that are scattered throughout most northern forested ecosystems are approximately $30 \%$ less than on "better" quality sites (Meng and Seymour 1992, Lautenschlager 1995). Therefore, although increased silvicultural intensity may increase volume production in some places, it is questionable whether total volume production could triple, much less provide the eight-fold increase envisioned by the Canadian Senate (Taylor 1999). Indeed, recent projections, based on modelling in Maine, suggest at most a three-fold increase from applying the most intensive cultural practices to spruce plantations on the best sites (Birdsay and Gadzik 1995).

\section{Silviculture Within the Timber Management Cycle}

Silvicultural systems are closely linked to harvesting and regeneration, and the system chosen is one indication of the silvicultural intensity being practised. Harvesting is a major silvicultural tool and harvest-related specifics, including season of harvest, equipment used, residual biomass, residual species composition, basal area, the degree of biomass removed, and site disturbance set the stage for post-harvest regeneration success, post-harvest competition (amount and vigour), and future crop protection requirements. Silvicultural treatments have been divided into 1) methods to favour reproduction (direct regeneration and/or methods that favour establishment), and 2) tending, or intermediate, treatments that take place at other times during the rotation. For both plantations and naturally regenerated stands [gymnosperms (conifers) and angiosperms (hardwoods)] opportunities for intensive silvicultural treatments exist throughout the rotation or timber management cycle (Fig. 1, Table 1). This cycle includes pre-harvest, harvest, establishment, and growth phases; during each phase, forest crop growth increases have been documented following silvicultural treatments (Lautenschlager 1999a). A prerequisite to entering the timber management cycle, however, is to place stand-level treatments into appropriate broader scales. Sustainable forest management (SFM) requires that part of that placement include developing a holistic (hence integrated) landscape-based management plan. That plan must include reforestation and protection designed to address both stand- and landscape-level considerations and objectives and be appropriate for stands within forests, forests within landscapes, and landscapes within their broader contexts (regions, provinces, countries, etc). [Bordelon et al. (2000) present a hierarchical framework for examining a variety of natural resource considerations when addressing stand, basin, district, and regional scales of landscape planning.] 


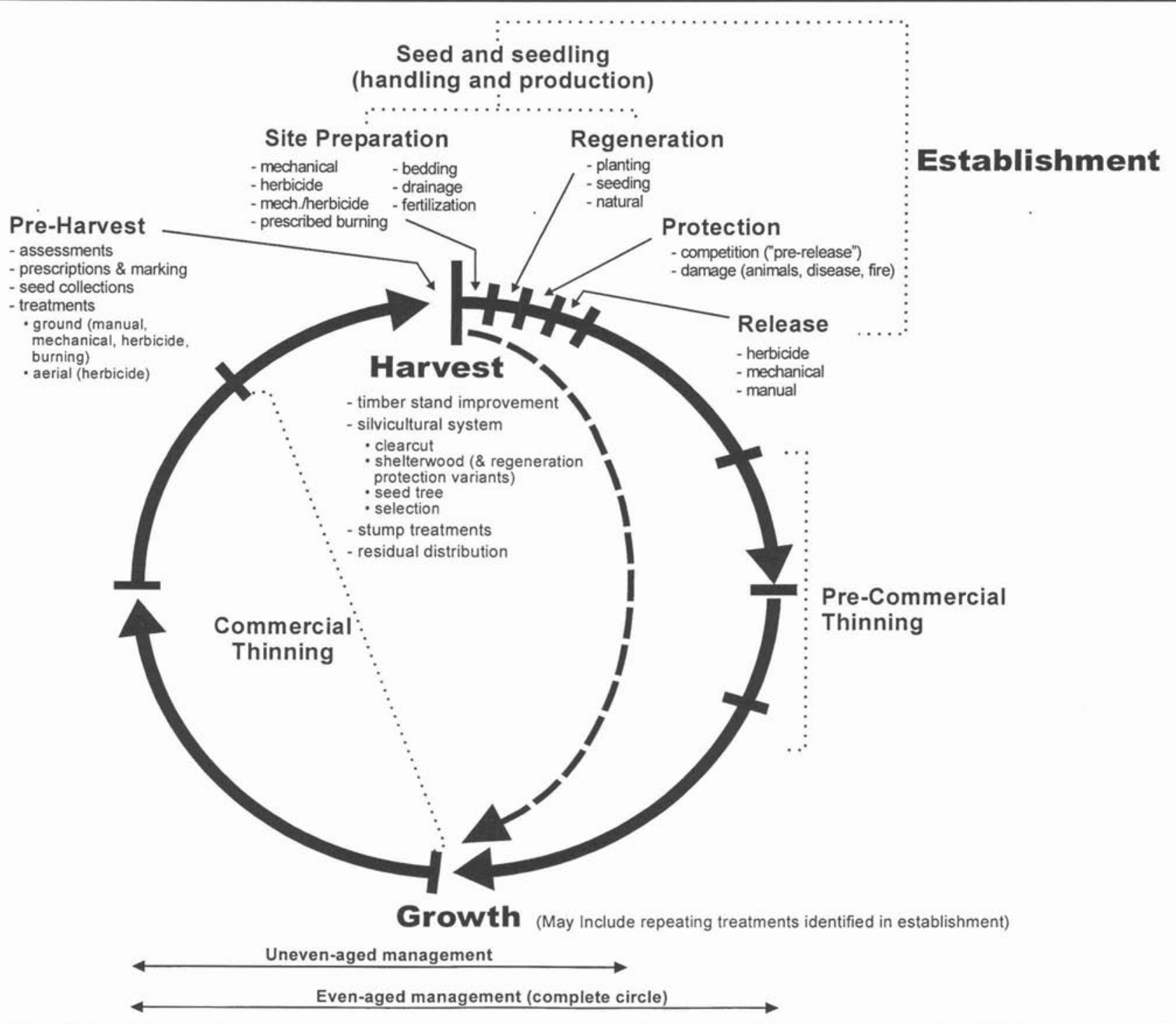

Fig. 1. Timber management cycle(s) including treatments, for even- (solid line) and uneven-aged (dashed line) management.

During the last three decades in North America forest management plans have commonly had an integrated natural resource management focus (Oliver 1999). However, zoning as a way to maintain natural resource components and values, although questioned (Sherry and Johnson 1999), is being embraced by many (Seymour and Hunter 1992, Binkley 1997, Taylor 1999). At the fibre production level, management plans must be based on clearly identified objectives and associated outputs (product types), and depending on the objectives, maintaining other, commonly non-fibre forest components or conditions within managed stands, forests, landscapes, or zones.

Perry (1998) outlined the following silvicultural practices that have been used, primarily in association with artificial regeneration, to increase fibre production and growth: "(a) rapid establishment of a new stand following harvest (nursery and planting practices); (b) maximizing the flow of site resources to the crop (controlling competing vegetation); (c) improving soil resources (fertilization, bedding, and drainage on some sites); (d) selecting and breeding fast-growing genotypes; and (e) minimizing losses due to insects, diseases, fire, and wind (stand protection)." An alternative outline, which I follow [similar to presentations by Walstad et al. (1987)], places silvicultural treatments within groups associated with operational timing within the timber management cycle (Fig. 1).

Table 1 outlines opportunities for intensive silvicultural treatments during a rotation or over several cutting cycles. Although interactions among silvicultural treatments are identified (footnotes in Table 1) the appropriate steps required to be considered intensive silviculture have not. Those steps will vary by forest type, management history, and management objectives, as well as site-specific resources and conditions. Therefore, appropriate steps will differ markedly among management units. Table 2 provides a synthesis of expected costs, growth responses, scientific concerns, and public concerns associated with specific treatments. However, an in-depth understanding of short- and longer-term costs, and biological and social consequences of individual treatments and treatment com- 
Table 1. Opportunities for intensive silvicultural treatments and related considerations and activities during a rotation or cutting cycle(s) [plantations and/or naturally regenerated stands - gymnosperm (conifer) or angiosperm (hardwood)].

\section{Pre-Harvest ${ }^{l}$}

- stand assessment (gene conservation, vertebrates, invertebrates, pathogens, succession, microsites), prescriptions, and marking

- seed collections ${ }^{2}$

- ground applied (manual, mechanical, herbicide, prescribed fire)

- aerial applied (herbicide)

\section{Harvest $^{3}$}

- thinning, timber stand improvement, or the silvicultural system chosen [clearcut, shelterwood, selection (+ regeneration protection variants), etc.]

- stump treatments (herbicide/fungicide)

- residual (cut and uncut) distribution (clumped or scattered)

\section{Establishment ${ }^{4}$}

- site preparation [mechanical, herbicide (ground or aerial), mechanical + herbicide, prescribed fire]

- bedding (mounding) and/or drainage

- seeding or planting 5 (genetic improvement ${ }^{6}$, stock type and testing, nutrient loading, mycorrhizal-inoculating)

- fertilization ${ }^{7}$

- minimizing losses caused by:

competing vegetation ${ }^{8}$ [herbicide (ground or aerial), mechanical, manual, combinations]

animals (insects and larger), wildfire, disease

environmental vagaries (wind, ice, floods, etc.)

Growth

- spacing and thinning ${ }^{8}$ [pre-commercial, commercial (potentially repeated ${ }^{9}$ ), timber stand improvement]

- fertilization ${ }^{7}$

- minimizing losses caused by:

competing vegetation $^{8}$ [herbicide (ground or aerial), mechanical, manual, prescribed fire, combinations]

animals (insects and larger), wildfire, disease

environmental vagaries (wind, ice, floods, etc.)

- pruning (where stem quality is a major concern)

${ }^{1}$ Develop a reforestation plan based on desired product outputs through time. Assess potentials, concerns, and sites, and collect seed if appropriate.

${ }^{2}$ Including production, processing, and minimizing stress (biological, chemical, and physical). Consider certification class, management and accounting, storage, preparation and sowing, quality, pests, watering/nutritional regimes, weeding, seedling handling, pre-storage, storage, transportation, and on-site storage.

${ }^{3}$ Harvest using an appropriate silvicultural system and prepare the site to optimize establishment success and growth potential of desirable species and/or individuals, and minimize risks to those from undesirable plants and animals (insects and larger), fire, disease, and environmental vagaries.

${ }^{4}$ Monitor the establishment (survival 1-3 months, plus 1 and 2 years after planting) through to "free-to-grow," and use that information to adjust site-specific needs to ensure maximum production and refine future reforestation efforts.

${ }^{5}$ Select the best site for the species being planted and match the seed source to planting macro- and micro-sites, but consider using species that may grow well but have been excluded from sites by competition or historical accident. Ensure a mix of genotypes within a plantation and use genetically superior seed sources where available. Prepare sites to "capture" natural seedfall and/or harvest to protect advance regeneration.

${ }^{6}$ Realistically restricted to areas that are planted.

${ }^{7}$ Fertilization has shown benefit on nutrient-poor sites, but in northern forested ecosystems it has commonly provided significant benefit only when combined with competition control. In many instances, competition control alone has provided benefits equal to those of fertilisation plus competition control.

${ }^{8}$ Competition control [pre-release, release, and pre-commercial thinning (spacing)] may be via herbicides, machines, both, or manual while competition control later in the rotation [commercial thinning (even-aged), selection cutting (uneven-aged), etc.] is commonly a mechanical treatment that provides both biological and economic (increasing merchantable volume on residual stems) value. Control competition to optimize the seedlings' access to warm micro-environments, provide moisture and nutrients, secure establishment, and achieve growth potential and stature in the stand. In northern even-aged managed forested ecosystems, this is critical during the first 5 years after establishment (planting or natural regeneration). In addition, it can provide growth benefit in both evenand uneven-aged managed forested ecosystems throughout their rotations or cutting cycles.

${ }^{9}$ Now commonly practised in Great Lakes-St. Lawrence tolerant hardwood forests, resulting in stands that are continuously improved.

binations is required before any treatment or treatment combination can be evaluated and the best for specific management units and objectives can be identified. [See McKenney (2000) for an analysis of the economics of intensive silviculture.]

\section{Wood Quality Concerns}

Increased silvicultural intensity is designed to increase growth rates of selected individuals, shorten rotations, and increase the potential for harvesting (potentially repeatedly) more young trees. Each of these variables could reduce wood quality. In conifers, the juvenile wood, commonly the bulk of production early in the rotation in more intensively managed plantations, has lower specific gravity, shorter tracheids, larger fibril angle, greater longitudinal shrinkage, lower percentage of latewood, more compression wood, thinner cell walls, larger cell diameter, higher lignin content, and lower cellulose content (Bendtsen 1978). Thus, a greater volume of wood from intensively versus extensively managed stands will be required to produce fibre-based products.

Smith et al. (1997) noted, however, that during periods of active increase in size, including height, the specific gravity and strength of the wood laid down tends to increase and that juvenile wood (as opposed to the denser, stronger late-wood) is normally produced only in parts of the boles of trees that are covered with living branches. In addition, they stress that wood age, not growth rate, is responsible for the weaker juvenile wood. Therefore, if following release a conifer grows more rapidly, it creates a greater volume of the kind of wood that would have been laid down without release; it does not shift to production of weak wood (Smith et al. 1997). Much of the focus of the 
Table 2. Overview ${ }^{1}$ of expected costs, growth responses ${ }^{2}$, scientific concerns, and public concerns associated with a single application of a variety of intensive silvicultural treatments. [NA $=$ not applicable, $?=$ unknown, $-=$ none, $*=$ little $($ low $), * *=$ moderate, $* * *=$ heavy $($ high $), * * * *=s e v e r e$ (very high)].

\begin{tabular}{|c|c|c|c|c|}
\hline Practice & Cost & $\begin{array}{c}\text { Growth } \\
\text { Response }\end{array}$ & $\begin{array}{l}\text { Scientific } \\
\text { Concern }\end{array}$ & $\begin{array}{l}\text { Public } \\
\text { Concern }\end{array}$ \\
\hline \multicolumn{5}{|l|}{ Pre-harvest } \\
\hline \multirow{4}{*}{$\begin{array}{l}\text { ground applied: manual } \\
\text { mechanical }\end{array}$} & $* * * *$ & $?$ & * & $*$ \\
\hline & $* * *$ & ? & ** & * \\
\hline & $* *$ & ? & - & ** \\
\hline & $* * *$ & ? & * & $* *$ to $* * * *$ \\
\hline aerially applied: herbicide & $*$ & ? & $*$ & $* * * *$ \\
\hline \multicolumn{5}{|l|}{ Harvest } \\
\hline thinning and/or stand improvement & $* *$ & - & ** & $*$ \\
\hline silvicultural systems & - & NA & $*$ & $*$ to $* * * *$ \\
\hline stump treatments (herbicide/fungicide) & $*$ & ? & * & $* * *$ \\
\hline residual distribution & $* *$ & $\dot{?}$ & $* * *$ & $*$ \\
\hline \multicolumn{5}{|l|}{ Establishment } \\
\hline \multirow{4}{*}{$\begin{array}{ll}\text { site preparation: } & \text { mechanical } \\
& \text { herbicide } \\
& \text { mechanical + herbicide } \\
& \text { prescribed fire }\end{array}$} & ** & * & $* * 3$ & * \\
\hline & * & $* *$ & $* 3$ & $* * * 4$ \\
\hline & ** & $*$ & $* * 3$ & $* * *$ \\
\hline & ** & * & ** & $* *$ to $* * * *$ \\
\hline bedding and/or drainage & $* *$ to $* * * *$ & ** & $*$ to $* * *$ & - to $* * * *$ \\
\hline seeding/planting & $* *$ & $* * 5$ & $* *$ & $*$ \\
\hline stock type and testing & * & * & - & - \\
\hline genetic improvement & $*$ & **6 6 & $*$ & $*$ to $* * * *$ \\
\hline nutrient loading & * & * & - & - \\
\hline mycorrhizal inoculation & $* *$ & * & - & - \\
\hline fertilization & * to **** & $* 6$ & $* *$ & * \\
\hline \multicolumn{5}{|l|}{ Minimizing losses caused by: } \\
\hline \multicolumn{5}{|l|}{ 1) competing vegetation } \\
\hline herbicide (ground or aerial) & * & $*$ to $* * * * 5$ & * & $* * * *$ \\
\hline mechanical & ** & $*$ & * & * \\
\hline manual/motor-manual & $* * * *$ & * & $*$ & * \\
\hline combinations (ground-based) & $* * * *$ & $*$ to $* *$ & $* *$ & $* * *$ \\
\hline \multicolumn{5}{|l|}{ 2) animals } \\
\hline insects & ** & $* * 7$ & $* * *$ & $* * * * 4$ \\
\hline mammals & ** & $* * 7$ & $*$ & $* * 8$ \\
\hline 3) wildfire & $*$ to $* * * *$ & $* * 7$ & $*$ & $* * 9$ \\
\hline 4) disease & $* * *$ & $?$ & $* * *$ & $* *$ \\
\hline 5) environmental vagaries & $* * 10$ & NA & - & - \\
\hline \multicolumn{5}{|l|}{$\begin{array}{l}\text { Growth } \\
\text { spacing and thinning }\end{array}$} \\
\hline pre-commercial & $*$ & $* *$ to $* * * *$ & * & $* 11$ \\
\hline commercial (once or repeated) & * & $* 12$ & * & $*$ \\
\hline stand improvement & * & $*$ to $* * * *$ & $*$ & $*$ \\
\hline \multicolumn{5}{|l|}{ fertilization and minimizing losses ${ }^{13}$} \\
\hline pruning & $* *$ & $* * 14$ & * & * \\
\hline
\end{tabular}

${ }^{1}$ A synthesis of views provided by R. A. Lautenschlager, Tom Sullivan, Bob Wagner, John Zasada, and Steve Colombo.

${ }^{2}$ Short-term responses only; many of these treatments have both short- and long-term consequences.

${ }^{3}$ Depends on percentage of area treated - full-site treatments (e.g., blading) of great concern; limited treatment (patch scarification) of limited concern.

${ }^{4}$ Less concern if ground applied; greater concern if aerially applied.

${ }^{5}$ May mean the difference between having a gymnosperm (conifer) crop quickly and not having that crop within the next century.

${ }^{6} \mathrm{Growth}$ responses often require or are improved by competition control.

${ }^{7}$ May be required to ensure that there is a forest crop to harvest

${ }^{8}$ Variable (* to $\left.* * * *\right)$ depending on the problem species and the control method(s) used.

${ }^{9}$ Public concern is associated with NOT controlling fires.

${ }^{10}$ Silvicultural treatments may help reduce losses.

${ }^{11}$ Minimal if mechanical treatments are used. Much greater if herbicides are used.

${ }^{12}$ Increase merchantable volume but total volume/unit area generally decreases.

${ }^{13}$ As suggested under Establishment (above).

${ }^{14}$ Reduces one wood quality concern (knots).

juvenile wood/wood quality issue has been the on effects of thinning; however, all of the treatments outlined under Establishment and Growth in Table 1 and the often-required combinations of treatments designed to increase fibre production are likely to affect wood quality.
Increased taper associated with planting at wider spacings is another concern associated with increasing silvicultural intensity. Shepard and Shottafer (1990) and Shepard et al. (1991) reported that dominant 77-year-old black spruce trees from a natural stand contained nearly twice the merchantable volume 
of dominant trees from a 29-year-old stand that had been released with a herbicide application and pre-commercially thinned, even though the average dbh of both was approximately $18 \mathrm{~cm}$. The younger trees simply had much greater taper. Still, early stand management, over time, seems capable of producing volumes like those from untreated areas in $25 \%$ less time.

Wood quality also affects interactions between the pulping process and the desired products: "In general, the farther the wood is from the pith, the greater the length, density, strength, cellulose content, and anatomical structural quality of the fibers" (Smith et al. 1997). Although used, low-density and knotty woods are not desirable for pulpwood. With its lower specific gravity, short-rotation wood produces lower chemical pulp yields per unit volume (Gladstone et al. 1970); however, it is not as undesirable as higher density wood (Haygreen and Bowyer 1989) and may actually be preferable for mechanical pulping (Carpenter 1984).

Pugel et al. (1990a,b) found that composites (flakeboard, particleboard, fibreboard) produced from loblolly pine juvenile wood were comparable to composites from mature wood in a number of strength and functional characteristics. However, juvenile wood composites had a higher compaction ratio, and $20 \%$ more juvenile wood was required to obtain a panel of equal density. Wood properties change during the juvenile period, and specific gravity is one property of interest to many manufactures. When grown naturally specific gravity differs among the common northern gymnosperm species, obtaining acceptable levels in 30 years for balsam fir (Abies balsamea), 50 years for black (Picea mariana) and white spruce (Picea glauca), and 60 years for red (Picea rubra) spruce (Shepard, personal communication). Thus, if higher specific gravity from shorter-rotation conifers is an objective, managers should consider both the potential for genetic improvements of and appropriate cultural practices for fir, a common native northern species that regenerates naturally and abundantly and grows rapidly across a variety of northern forest ecosystems.

For solid wood, density is probably the most important property affecting the strength of clear lumber, while size and frequency of knots is the most important characteristic controlling the grade for structural lumber (Kellogg and Kennedy 1986). Solid-wood products from intensively managed forests commonly have strength and structural weaknesses, will likely be valued less than those cut from naturally regenerated, untended stands. Thus, solid wood will likely continue to lose market share to composites (Balter and Berg 1999), which are increasingly convincingly covered with either visually appealing paper-thin wood or "wood-like" veneer. Wood quality concerns seem to be less serious with diffuse-porous hardwoods, soft pines, true firs, and spruces, which show little contrast between early and late wood (Smith et al. 1997). These species groups, therefore, provide the best opportunities to grow desirable highly homogeneous wood on shorter rotations.

\section{Unresolved Questions}

The silvicultural treatments identified in Table 1 could be manipulated at various times during a rotation to adjust species composition and stocking, increase survival, increase merchantable volume, shorten rotations, and increase the quality of fibre coming from managed stands. However, only site preparation, genetic improvements, stock type and testing conifer release with herbicides, and thinning have been inves- tigated in detail or with rigour. Furthermore, treatments with potential, like fertilization and exotics, are not approved for some northern jurisdictions. Therefore, the following questions remain:

1) Will intensive silvicultural treatments (single, repeated, or combined) increase forest crop growth? If so, at what cost, for what species, and for how long?

2) In what order, or in what combination, should intensive silvicultural treatments be implemented to provide the greatest economic return (i.e., what are the biological and economic consequences of an intensive silviculture version of Liebig's law of the minimum)? How does Liebig's law, which suggests that production is limited by the lowest stave in the barrel (Fig. 2), vary with repeated treatments or combinations?

3) Could the benefit of early and repeated competition control, which has dramatically increased gymnosperm volume production, be achieved by a single strategically timed treatment or by appropriate combinations of earlier treatments (e.g., site preparation immediately after harvest followed by planting with stock that is larger, genetically improved, tested inoculated with mycorrhizae, and/or nutrient-loaded)?

4) How do potential economic advantages vary by plant groups, species, forest types, site types, latitude, and predicted changes in climate and pollution?

\section{Other Concerns}

\section{Fibre production and markets}

Global wood use has increased over $40 \%$ in the past 25 years (McCullough 1999), with production from 11 major industrial wood-producing nations increasing $70 \%$ between 1977 and 1995 , up 25\% in the US and Canada, 58\% in New Zealand, and $195 \%$ in Chile (Campinhos 1999). With expected continual increases in the global standard of living, wood fibre demand could increase seven fold over the next 50 years (Sutton 1999).

Much of the world's fibre supply now comes from intensively managed plantations in the warmer parts of the world (Sedjo 1999), where timber growth rates commonly exceed $20 \mathrm{~m}^{3} / \mathrm{ha} / \mathrm{yr}$ (Wilson and Arthur 1998). In cooler northern ecosystems, growth rates are commonly less than $5 \mathrm{~m}^{3} / \mathrm{ha} / \mathrm{yr}$ (Wilson and Arthur 1998). In Canada and elsewhere, intensive silviculture has been touted as a way to address the increasing demand for fibre (Taylor 1999), yet forest industry seems to have adapted to the increased demand, to this point, by developing new technologies that use lower-cost fibre, producing reconstituted or composite wood products.

Over the last 20 years, composites (plywood, panelling, particleboard, chipboard, oriented strandboard, etc.) have rapidly gained an increasing share $(30-60 \%)$ of previously solid wood markets (Wernick et al. 1998, Balter and Berg 1999). Therefore, fibre-based products of the future are likely to increasingly differ from those produced two decades ago. Due primarily to price but also to strength and structural characteristics, fibre for most construction uses will increasingly be some form of composite, coming from dramatically younger, lowervalued trees and forests that are common, often naturally occurring throughout the world (Cohen, D., Associate Prof., Forest Products Marketing and Management, Faculty of Forestry, University of British Columbia, Vancouver, BC., personal communication, 1999). Cohen believes that although solid wood will likely continue to have a place in world markets, 


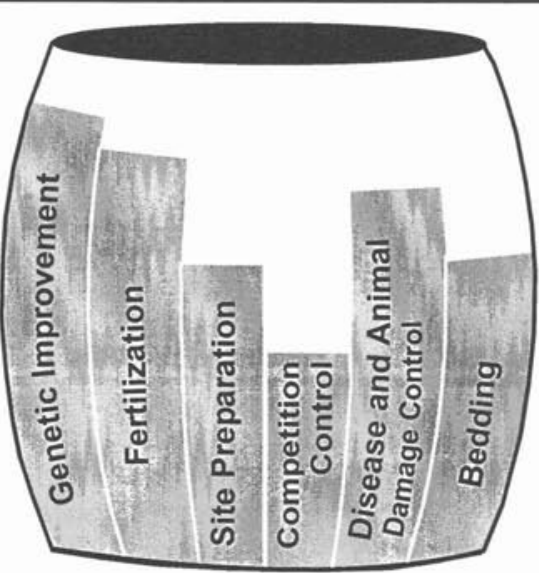

Fig. 2. An intensive silviculture version of Liebig's law (which suggests that production is limited by the lowest stave in the barrel) relative to hypothetical biological consequences of individual treatments.

that place will soon be limited to certain niches. If markets increasingly favour low- or lower-cost fibre, an oversupply of previously desirable fibre (timber) may result, reducing prices for what many foresters concentrate on growing today.

Sutton (1999) stated that economic realities will lead to a greater emphasis on agricultural approaches to gymnosperm and/or angiosperm fibre production. Concerned foresters should consider adjusting their silvicultural strategies and inputs (i.e., reconsider treatments and approaches outlined in Table 1) to address this reality. They may also want to start to emphasize economically justifiable agricultural approaches to culturing and harvesting dramatically younger stands for fibre as opposed to producing timber.

Any increased use of an agricultural approach will eventually lead to a greater emphasis on maintaining and/or augmenting site productivity, minimizing biotic and abiotic damaging agents, and securing optimal site occupancy and growth in both space and time. In Oregon, Washington, California and elsewhere around the world (South America, Africa, Australia, New Zealand), hybrid poplar (Populus spp.) and eucalyptus (Eucalyptus spp.), the most widely planted angiosperm species in the world (Turnbull 1999), provide wood fibre in 5 to 10 years (Boyle 1999). Balter and Berg (1999) state that as North American fibre demands become tighter industry should expect intense competition from offshore producers.

\section{Fibre productivity data concerns}

Depending on the markets, which are opportunistic, traditional forest production information may be inappropriate or inadequate. If future markets primarily pay only for inexpensive fibre it will likely come from early successional species managed for maximum production during one or a few decades. However, no information is available about the productivity potential for former non-crop species in northern forest ecosystems. Nor has sufficient information been gathered about species and/or genotypes that can produce quickly and abundantly during short rotations on available, potentially productive northern sites.

In addition, even if more traditional silvicultural approaches continue, retrospective production analysis consistently fails to document their production potential. Retrospective analysis has not (and cannot) capture the elimination of species that may have been on a site but were out competed (Kotar and Coffman 1982, Newton et al. 1992), the growth lost to competition even if the desired species survive (Newton et al. 1992), or species (natives or exotics) that could grow well but do not because they have never been actively cultured on those sites. Newton et al. (1987) noted that because site index curves are based on breast height-over-age relationships, potential yields of conifers in the northeast and lake states/provinces, particularly those growing on good sites and free of competing vegetation, tend to be greatly underestimated.

In Ontario, forest scientists have been recording the growth of several gymnosperm species on a variety of sites where competition has been controlled annually (Wagner et al. 1995). Those studies have demonstrated a two- to six-fold (depending on sites and species) increase in conifer volume growth associated with release from competition alone. However, conifer release is only one of several silvicultural treatments commonly used to increase growth (Table 1). To document maximum growth potential associated with specific treatments, those treatments must be examined in greater detail both on their own and in combination with other treatments (site preparation, bedding, fertilization, genetic improvement, etc.), with different genotypes and species on a variety of sites and latitudes. In addition, research must be conducted to determine the fibre production potential, wood quality, milling possibilities, etc., for non-traditional species such as willow (Salix spp.), alder (Alnus spp.), aspen (Populus spp.), and others (Evers et al. 1983) when planted and cultured, on their own or in combinations, across a range of potentially productive northern sites.

Binkley's (1997) statements that the site-index curves in current use consistently understate stand productivity and that in some places the actual site index is $85 \%$ higher than the figures used for current timber supply analysis suggest serious problems with existing forest production information. Those statements also suggest that forest managers in British Columbia, and other northern jurisdictions (Frayer and Furnival 1999), have a limited understanding of fibre resource availability as well as the connection between their inventory and productivity. Simply improving and updating the fibre resource inventory might help elevate current forest fibre shortfall fears. Without an accurate, appropriately updated fibre resource inventory directly coupled with growth and production predictions, forest managers at all levels will have difficulty predicting stand, forest, or regional production potential, regardless of the degree of silvicultural intensity employed or planned.

\section{Is Intensive Silviculture Sustainable?}

If intensive silviculture is to contribute to human welfare, it must be an ecologically/socially sustainable component within a larger, ecosystem management, context. With the advent of "ecosystem management" (Grumbine 1994, Lautenschlager and Browning 1997), increasing emphasis has been placed on blending ecological (including biological) and social (including economic and cultural - Jakes 1996) realities and values to assure that managed ecosystems meet present and future public needs (WCED 1987; Lautenschlager 1996, 1998a; Messier and Kneeshaw 1999). Chapin et al. (1996) stated that "A sus- 
tainable ecosystem is one that, over the normal cycle of disturbance events, maintains its characteristic diversity of major functional groups, productivity, and rates of biogeochemical cycling... determined by a set of interactive controls that both govern and respond to ecosystem processes." Sustainability has been called a quest, a process, a set of ideas and actions in gestation, development and evolution (Boyle 1999); more a philosophy than a definable condition or set of acceptable management practices (Flasche 1997, Lackey 1998). The term sustainable forest management (SFM) has been used loosely (Sims et al. 1996), but it is my belief that the foundation for SFM is the integration of specific social and ecological concerns and knowledge to direct management at that time.

\section{Certification}

Certifying the sustainability of forest management and related production is one approach to quantifying SFM (i.e., integrating social and ecological needs), and will likely be required to document that any intensive silvicultural approach is sustainable. Certification approaches are commonly linked to broadscale, internationally recognized criteria and indicators of SFM (CCFM 1995, 1997). Companies meeting standards become certified and with one approach their products are identified (labelled) in the marketplace. Certification addresses the realities of the global market, reassuring consumers that their purchases come from forests that are managed sustainably. North America presently has four forest certification approaches: International Organization for Standardization (ISO), Sustainable Forestry Initiative (SFI), Forest Stewardship Council (FSC), and the Canadian Standards Association (CSA). All except SFI have third-party review, and only FSC, which is performance- as opposed to systems-based is intended for product labelling (Mater et al. 1999). Although ISO and FSC are being examined or have been used to monitor and then certify SFM in some Canadian forests, only the CSA, which was developed by a coalition of 23 forest industry associations from across Canada and the Canadian Standards Association (Lapointe 1998), has a clear Canadian focus.

Until there is broad-based agreement about exactly what constitutes SFM, which I have argued will be tied to local specifics integrated with cultural and ecological concerns across increasingly broader scales (Lautenschlager 1998a), forest management certification may continue to flounder. Even if certification becomes the norm, it remains unclear whether the majority of consumers will pay a premium for certified products (Sedjo et al. 1998, Spinazze and Kant 1999). In addition, because certification is primarily a means for foresters and sometimes millers to attempt to satisfy the environmental concerns of consumers, it is unlikely that anything less than a performance-based approach will ever be judged acceptable. Environmentally astute consumers, or groups representing them, will want to know exactly what foresters hoped to accomplish with specific management practices, if that was achieved during the designated management period, and what independent auditor verified the results. In addition, they will also want to know if the goals and objectives were reasonable (if components they care about were protected) and therefore will increasingly want to contribute to specific objectives for the next round of management (Lautenschlager 1999b). If intensive silviculture is to be judged to be SFM, and hence certifiable, it will be because it will be practised as part of a broader scale integrated landscape management approach.

\section{Intensive silviculture and landscape management}

Fifty years ago, Aldo Leopold recognized and advocated silvicultural manipulations in enlightened land management. He stated, "A land ethic of course cannot prevent the alteration, management, and use of ... soils, waters, plants, and animals, but it does affirm their right to continued existence, and at least in spots, their continued existence in a natural state" (Leopold 1966). Environmentalists who accept Leopold's view do not advocate managing for natural forests everywhere; rather they believe that management should be directed at ensuring that forests continue to exist everywhere and that some are natural (Lautenschlager 1998b). Implementing intensive silviculture in some places across the landscape could easily be viewed as ecosystem management because having everything everywhere (stand-level, multiple resource management) is not desirable, practical, or possible (Lautenschlager 1999b).

Placing intensive silviculture into an ecosystem management context could involve partitioning the land base into different use types or zoning (Hunter 1990, Seymour and Hunter 1992, Binkley 1997, Taylor 1999). In New Zealand, forests are divided into natural or intensively managed plantations. Hunter (1990) and Seymour and Hunter (1992) suggest that forest land should be partitioned into high yield (intensive management), general management (extensive), and special value and protected areas, similar to recent suggestions for Ontario (OMNR 1999a) and Canada (Taylor 1999). Binkley (1997) suggests that zoning in British Columbia should include intensive timber production, integrated use, and protected zones. In 1999 the Canadian Senate suggested that $20 \%$ of the boreal forest should be intensively managed, $60 \%$ managed less intensively, and $20 \%$ be set aside as protected areas (Taylor 1999). Although Sherry and Johnson (1999) suggested that Binkley's strategy has serious flaws from ecological and aboriginal standpoints, others believe that with proper placement, zoned intensive silviculture should be compatible with maintaining all desirable ecological components across the managed landscape (Messier and Kneeshaw 1999). Indeed, Seymour and McCormack (1989) argue that production increases from high-yield silviculture will dramatically decrease the need to manage most of the land base, leaving the bulk of the land available for multiple uses. Experience, however, has shown that when new fibre sources are identified mills use them as additions to, rather than replacements for, established sources.

Although timber and fibre provide significant economic benefits to local and broader scale economies, other values such as ecotourism (Theophile 1995) and non-timber products (Emery 1999), including pharmaceuticals (Mohammed 1999), fur, fish, and wildlife (McKenney and Sarker 1994, Legg 1997), as well as environmental services (ecological life-support systems - Costanza et al. 1997) both enrich and help maintain related economies and ecosystems. Even excluding the high cost calculated for environmental services (which are literally irreplaceable - Costanza et al. 1997), other non-timber, or speciality, forest products may provide economic value as great or greater than that available from timber or fibre production (Burton et al. 1992). 
Mohammed (1999) categorized non-timber products as foods, health and personal care, materials and manufacturing supplies, environmental, landscape and garden, and decorative and aesthetic and suggested that collectively these have high personal and economic value. Emery (1999) simply suggested that speciality forest products have livelihood, cultural, and recreational values. Livelihood values have both non-market and market uses, cultural values include the continued ability to observe special practices and transfer knowledge among generations, and recreational values combine the peace and pleasure of being outdoors with a practical and useful activity.

Consumptive and non-consumptive wildlife use, fishing, and trapping fall into this recreational values category, and their collective contributions to the health and well-being of participants as well as local economies can be large (McKenney and Sarker 1994). For instance economic information for Ontario for the mid-1990s (Legg 1997) indicate that although forest product shipments exceeded $\$ 11$ billion/year, wildlife pursuits and recreational fishing contributed $\$ 4$ billion/year, while fur harvesting contributed $\$ 16$ million. McKenney and Sarker (1994) provide similar figures for the early 1990s; however, they caution that those figures should be weighed against current and future benefits, services, and values. They go on to say that statistics like those provided above do not, as a general rule, help decision-makers, and non-wood services are difficult to define and quantify (McKenney and Sarker 1994). Emery (1999) also noted that livelihood, cultural, and recreational values are qualitatively and quantitatively different from those that are captured by standard macroeconomic calculations. Costanza et al. (1997) calculated the value of natural capital and ecosystem services provided by the environment, and although their results have been questioned, the values predicted outweigh the value associated with timber, fibre, forest plants, fish, wildlife, and recreational use.

\section{Silvicultural Intensity and Production}

Increasing silvicultural intensity has costs and benefits (McKenney 2000). For angiosperms (hardwoods) in southern ecosystems, great benefits have come from short rotations (Turnbull 1999), while in northern ecosystems benefits have come from systematic rigorous pre-harvest assessments, prescriptions, and marking followed by judicious periodic thinnings (Nyland 1996). In tolerant hardwoods, thinnings are commonly designed to improve the quality of intermediate age classes, with benefit increasing with thinning intensity and decreasing with dbh (Nyland 1996). To date, conifer fibre production benefits have consistently come from treatments during the establishment phase. Not surprisingly, techniques with proven operational benefits, site preparation and conifer release, are now standard silvicultural practice across much of Canada's forests and in other northern boreal and boreal mixedwood ecosystems (CCFM 1996, Puettmann and Ek 1999). In conifer plantations, the growth associated with competition control has increased in direct proportion to the degree and duration of control (Lautenschlager 1999a). Across forested landscapes, habitat changes caused by controlling competitive vegetation can also help reduce browsing of forest crops by a variety of mammals (Walstad et al. 1987, Black 1992, Newton et al. 1992, Lautenschlager and Voigt 2000). In addition, although a single release treatment sometimes provides only a marginal growth increase, it often ensures that conifers survive (Newton et al. 1992) and are maintained within harvested northern landscapes.

In planted northern forests, dramatic conifer growth increases have followed repeated release treatments, and critical application periods, generally one to four years after establishment - have been identified (Wagner et al.1999). Impressive growth responses by naturally regenerated northern conifers following release are also common (Newton et al. 1992), as are growth increases by both gymnosperm and angiosperm species across North America and throughout the world (Stewart et al. 1984, Walstad and Kuch 1987, Wagner and Thompson 1998).

Repeated applications of any silvicultural treatment have repeated costs, and for conifers the early and repeated herbicide treatments have both financial and social consequences. In North America most publics are opposed to herbicide use in general and aerial herbicide use in particular; however, they are much less opposed to mechanical vegetation control treatments, such as those commonly used in site preparation (Wagner et al. 1998). Therefore, any form of herbicide application will lead to conflicts with concerned publics, and repeated applications will likely lead to repeated conflicts. However, for many publics the psychological value of land use designations (knowing the location of specific use areas) could reduce some or many of these conflicts. Finally, and importantly, it remains unclear whether post-treatment conifer crop tree volume increases will continue throughout the rotation without additional inputs (Perry 1998).

\section{Conclusions}

The successful management of northern forested ecosystems via increased silvicultural intensity will require cooperation among governments, industry, and individuals, leadership, action, social acceptance, and adherence to national and international treaties and agreements. It will require the integration of cultural and ecological knowledge plus communications among interested parties as they collectively identify desirable outputs from a combination of unmanaged, occasionally managed, and more intensively managed forest ecosystems. The foundation for the integrated landscape management that will be required for intensive silviculture to be successful must include a thorough social and ecological analysis, synthesis, and consensus about potential management scenarios. Economically unjustifiable choices, once made, could make it difficult, if not impossible, to obtain true value from forests grown under other less intensive approaches (Oliver 1999), and difficult to justify less intensive approaches with time (Benson 1988).

So, what are the choices? First, intensive silviculture could simply be part of the knowledge-intensive integrated management outlined by Oliver (1999) - more thoughtful multiple use management. Second, and more likely, intensive silviculture could build on existing silvicultural approaches, focussing on testing, understanding, increasing biological efficacy, and minimizing costs of treatments already developed and frequently used. This would require improving our understanding of the value of standard treatments, potentially repeated or in combination with others, and the effects of the most promising when applied to a variety of species (potentially genetically improved and fertilized), on a variety of site types where competition was controlled. The two- to six-fold volume increases seen to date following repeated conifer release treatments may be modest relative to what could be achieved with integrated inten- 
sive silviculture. Indeed, for some sites the eight-fold increases suggested by the Canadian Senate could be conservative. However, the cost of potential incremental increases remains unclear, as do the effects of specific treatment-related increases on wood quality and damage from animals, disease, and other biotic and abiotic stressors.

Third, the way silviculture is practised in northern ecosystems could change dramatically. New approaches could use new or existing treatments or techniques and integrate fieldfocussed efforts with knowledge and needs of wood technologists, harvesters, and millers. This could easily lead to focussing on producing low-cost fibre for composite markets and dramatically reducing efforts to culture larger trees. If fibre, as opposed to timber, production becomes the focus, emphasis will increasingly be placed on the equipment used throughout the rotation and less on historical silvicultural treatments and systems. Silvicultural practices under this scenario will likely be much more like agriculture than traditional forestry. (Unfortunately, like the watchmakers who had difficulty adapting to the digital world, traditional silviculturists and related researchers may be reluctant to examine fibre- rather than timber-based approaches to production for the future.)

Fourth, and more realistically, intensive silviculture could involve increased attention to integrated landscape management and include some components of the first three approaches, but with an increasing emphasis on fibre as opposed to timber production. Even if increased silvicultural intensity produces the predicted gains, however, the remaining forest ( $40-80 \%$ of that in use) will continue to require some degree of management to maintain the variety of values society expects. Therefore, in addition to identifying and zoning areas for specific uses, foresters should start to reconsider where (sites, forests, regions) the greatest gains from intensive silviculture will likely be achieved and how the economics of intensive silviculture and alternative land uses compare among these areas. For example, in much of the productive forest region of northern Ontario, the average growing season is 170 days; in southeastern Ontario it averages 210 days; and in much of southwestern Ontario, it averages 230 days. Although the choice may seem obvious, focussing intensive silviculture in southwestern Ontario may not be economically viable, due to greater land costs, increased need for vegetation control, and the historic agricultural use of that area. As energy costs increase, advantages associated with producing fibre close to mills or related infrastructure also increase. Therefore, at local and broader scales, the productive ability of potential fibreproducing species on less-than-prime sites, near roads, mills, and transportation centres and markets, as well as production on better sites across latitudes, needs to be thoroughly investigated.

The variety of silvicultural treatments examined in this paper either have been or could be used to increase timber or forest fibre production in northern forested ecosystems. Still, physiological, climatic, and social constraints, as well as previously established higher uses suggest that much of our naturally less productive northern forested land base is far from ripe for economically justifying increasing silvicultural intensity. Even so, those who continue status quo forest management solely may become less competitive. Calls for increased silvicultural intensity are based on the recognition that status quo management could result in the need to increase fibre imports to satisfy pro- ducers and consumers and that selective increases in intensity in the north could provide economic and ecological benefits (Lautenschlager 1994). Although the bold could reap great rewards by selectively increasing silvicultural intensity, unless their plans are scientifically based and socially acceptable, they could suffer the greatest losses. Before reasonable silvicultural directions and associated integrated landscape management plans can be developed, responsible parties need to agree on the most realistic and favourable (ecologically/socially responsible) approach(es) that are predicted to be economically competitive with production in other parts of the world. Price has been and will continue to be a major factor influencing forest product consumption, and that alone suggests that composites will increasingly dominate forest fibre markets and that SFM certification will only influence consumption if product choices have a similar price.

\section{Acknowledgements}

This paper benefited greatly from contributions (some incorporated directly into Table 1) made by Marilyn Cherry, David DeYoe, Steve Colombo, and Blake MacDonald; contributions to Table 2 made by Tom Sullivan, Bob Wagner, and John Zasada; reviews by Peter Nitschke, Cathy Nielsen, Bill Parker, Harri Liljalehto, Mike Irvine, Dan McKenney, and Jim Rice; graphics prepared by Trudy Vaittinen; French translation by Jean-Noël Candau; and editorial suggestions from Wendeline Price and Abby Obenchain.

\section{References}

Armson, K.A. 1979. Incentives for intensive forest management a view from Ontario. Pulp \& Paper Canada. 80(6):94-97.

Armson, K.A., W.R. Grinnell and F.C. Robinson. 2000. The history of reforestation in Ontario. In R.G. Wagner and S.J. Colombo (eds.). Regenerating the Canadian Forest: Principles and Practice for Ontario. Fitzhenry and Whiteside, Markham, ON.

Balter, K. and R. Berg. 1999. Prospect for Ontario's forest products sector in a global perspective. Resource Information Systems, Inc., Report (June 1999) to the Ont. Min. of Nat. Res., For. Manage. Branch, Sault Ste. Marie, ON. 34 p.

Baker, F.S. 1950. The Principles of Silviculture. McGraw-Hill, New York, NY. 414 p.

Bendtsen, B.A. 1978. Properties of wood from improved and intensively managed stands. For. Prod. J. 28(10): 61-72.

Benson, C.A. 1988. A need for extensive forest management. For. Chron. 64(5): 421-430.

Binkley, C.S. 1997. Preserving nature through intensive plantation forestry: The case for forest land allocation with illustrations from British Columbia. For. Chron. 73(5): 553-559.

Birdsey, R. and C. Gadzik. 1995. Timber supply outlook for Maine. Maine Dept. of Cons., Maine Forest Service, Augusta, ME. $40 \mathrm{p}$.

Black, H.C. (ed.). 1992. Silvicultural approaches to animal damage management in Pacific Northwest forests. Gen. Tech. Rep. PNW-GTR287, USDA For. Serv. 422 p.

Bordelon, M.A., D.C. McAllister and R. Holloway. 2000. Sustainable forestry Oregon style. J. For. 98(1): 26-34.

Boyle, J.R. 1999. Planted forests: views and viewpoints. New Forests 17: 5-9.

Brown, J.R., J. Herrick and D. Price. 1999. Managing low-output agroecosystems sustainably: the importance of ecological thresholds. Can. J. For. Res. 29(7): 1112-1119.

Burton, P.J., A.C. Balisky, L.P. Coward, S.G. Cumming and D.D. Kneeshaw. 1992. The value of managing for biodiversity. For. Chron. 68(2): 225-237. 
Campinhos, E. Jr. 1999. Sustainable plantations of high-yield eucalyptus trees for production of fiber: the Aracruz case. New Forests 17: 129-143.

Carmean, W.H. 1996. Forest site-quality estimation using forest ecosystem classification in northwestern Ontario. Environ. Monitor. and Assess. 39: 493-508.

Carpenter, C.H. 1984. The mechanical pulping of southern pine containing relatively large amounts of spring and juvenile fiber. In Proc. Symp. On Utilization of the changing wood resource in the southern United States pp. 124-146. School of Forest Resources, N.C. State Univ., Raleigh, NC.

Canadian Council of Forest Ministers (CCFM). 1995. Defining sustainable forest management: A Canadian approach to criteria and indicators. Nat. Res. Can., Can. For. Serv., Ottawa, ON. 22 p.

Canadian Council of Forest Ministers (CCFM). 1997. Criteria and indicators of sustainable forest management in Canada. Technical Report. Nat. Res. Can., Can. For. Serv., Ottawa, ON. 137 p.

Canadian Council of Forest Ministers (CCFM). 2000. National Forestry Database Program [On-line database, annual update] http://nfdp.ccfm.org.

Canadian Forest Service (CFS). 1995. Silvicultural terms in Canada. ( $2^{\text {nd }}$ ed.) Nat. Res. Can., Can. For. Serv., Ottawa, ON. 109 p. Chapin III, F.S., M.S. Torn and M. Tateno. 1996. Principles of ecosystem sustainability. American Naturalist 148(6): 1016-1037.

Corns, I.G.W. 1992. Forest site classification in Alberta: its evolution and present status. For. Chron. 68(1): 85-93.

Costanza, R. et al. 1997. The value of the world's ecosystem services and natural capital. Nature 387(5): 253-260.

Dietz, J. 1997. Unique Ontario thinning show. Logging and Sawmilling Journal. (Nov.) 27-28,30.

Duerr, W. A. 1960. Fundamentals of Forestry Economics. McGrawHill, New York, NY.

Evers, R.W., W.E. Raitanen and B.A. Barkley. 1983. The genetic resource In New Forests in Eastern Ontario - Hybrid Poplar. pp. 9-35. Ontario Ministry of Natural Resources, Queen's Printer for Ontario, Toronto, ON.

Emery, M.R. 1999. Social values of specialty forest products to rural communities. In S. Josiah (ed.). Proceedings of the North American conference on enterprise development through agroforestry: Farming the agroforest for specialty products. Univ. Minn., St. Paul, MN. (In press).

Flasche, F. 1997. Presentation to the II international Forest Policy Forum, Solsona, Spain, March 12.

Frayer, W.E. and G.M. Furnival. 1999. Forest survey sampling designs - A history. J. For. 97(12): 4-10.

Gladstone, W.T., A.C. Barefoot and B.J. Zobel. 1970. Kraft pulping of earlywood and latewood for loblolly pine. For. Prod. J. 20(2): 17-24.

Grumbine, R.E. 1994. What is ecosystem management? Conservation Biology 8: 27-38.

Hartig, G.L. 1795. Anweisung für die Taxation der Forste order zur Bestimmung des Hokertrags der Wälder. Heger Verlag, Giessen, Germany.

Haygreen, J.G. and J.L. Bowyer. 1989. Forest products and wood science: An introduction - 2nd ed., Iowa State University Press, Ames, IA.

Helms, J.A. (ed.). 1998. The Dictionary of Forestry. The Society of American Foresters, Bethesda, MD. 210 p.

Hunter, M.L. Jr. 1990. Wildlife, forests, and forestry. Principles for managing forests for biodiversity. Prentice Hall, Englewood Cliffs, NJ. 370 p.

Jakes, P.J. 1996. Evaluating the social and economic impacts of riparian management practices. In At the water's edge: the science of riparian forestry conference proceedings. pp. 129-133, Ext. Bull. BU-6637S, Univ. of Minn., St. Paul, MN.

Kellogg, R.M. and R.W. Kennedy. 1986. Implications of Douglasfir wood quality relative to practical end use. In C.D. Oliver, D.P. Han- ley and J.A. Johnson (eds.). Douglas-fir: Stand management for the future. pp. 97-102. Contribution No. 55, Inst. For. Resour., Col. For. Resour., Univ. Wash., Seattle, WA.

Kotar, J. and M.S. Coffman. 1982. Application of habitat type concept to regeneration of conifers in the upper Great Lakes region. In G.D. Mroz (comp.). Proceedings: Artificial regeneration of conifers in the upper Great Lakes region. pp. 53-64. Mich. Tech. Univ., Houghton, MI.

Kryzanowski, T. 1998. Alberta studies tree farm tenure system. Logging and Sawmilling J. 29(10): 5-6.

Lackey, R.T. 1998. Seven pillars of ecosystem management. Landscape and Urban Planning: 21-30.

Lapointe, G. 1998. Sustainable forest management certification: The Canadian programme. For. Chron. 74(2): 227-230.

Lautenschlager, R.A. 1994. A new paradigm and a loony will still buy a coffee. For. Chron. 70(5): 521 .

Lautenschlager, R.A. 1995. Competition between forest brush and planted white spruce in north-central Maine. Northern Journal of Applied Forestry. 12(4): 163-167.

Lautenschlager, R.A. 1996. Identify the specifics: A biopolitical approach for establishing research priorities. J. For. 94(4): 31-34. Lautenschlager, R.A. 1998a. From rhetoric to reality: Using specific environmental concerns to identify critical sustainability issues. Ecosystems 1: 176-182.

Lautenschlager, R.A. 1998b. Aldo Leopold - Thinking like a forester. For. Chron. 74(5): 697-699.

Lautenschlager, R.A. 1999a. Intensive silviculture - Part of Ontario's new "Living Legacy.” For. Chron. 75(3): 535.

Lautenschlager, R.A. 1999b. Improving long-term forest ecology research for the $21^{\text {st }}$ century. For. Chron. 75(3): 477-480.

Lautenschlager, R.A., T.P. Sullivan and R.G. Wagner. 1995. Using herbicides for wildlife management in northern ecosystems. New Zealand Forest Research Institute Bulletin 192: 152-154.

Lautenschlager, R.A. and M.R. Browning. 1997. Developing an ecosystem approach to achieving ecological sustainability - OMNR science forum overview. For. Chron. 73(2) :267-271.

Lautenschlager, R.A. and D. Voigt. 2000. Effects of forest regeneration practices on wildlife. In R.G. Wagner and S.J. Colombo (eds.). Regenerating the Canadian Forest - Principles and Practice in Ontario. pp. ?-?. Fitzhenry and Whiteside, Markham, ON.

Legg, D. 1997. Socioeconomic fact sheets (Caveats, Commercial Wild Fur Harvesting, Forest Products Industry, Recreational Fishing, Wildlife). Ont. Min. Nat. Res., Anal. and Plan. Serv., Peterborough, $\mathrm{ON}$,

Leopold, A. 1966. A Sand County Almanac. Oxford University Press, Inc. From Ballantine Books, New York. 295 p.

Mater, C.M., V.A. Sample, J.R. Grace and G.A. Rose. 1999. Thirdparty, performance-based certification. J. For. 97(2): 6-12.

McColm, R.G. 1986. Forest site classification in the northern region. In G.M. Wickware and W.C. Stevens. Proceedings: Site classification in relation to forest management. pp. 88-91. Canadian Forest Service, Great Lakes Forestry Centre, Sault Ste. Marie, ON.

McCullough, R.B. 1999. Four common myths about plantation forestry. New Forests 17: 111-118.

McKenney, D.W. 2000. What's the economics of intensive silviculture? For. Chron. 76(2): ?-?.

McKenney, D. and R. Sarker. 1994. An overview of non-wood valuation efforts in Ontario. For. Chron. 70(1): 47-54.

Meng, X. and R.A. Seymour. 1992. Influence of soil drainage on early development and biomass production of young herbicidereleased fir-spruce stands in north central Maine. Can. J. For. Res. 22: 955-967.

Messier, C. and D.D. Kneeshaw.1999. Thinking and acting differently for sustainable management of the boreal forest. For. Chron. 75(6): 929-938.

Mohammed G.H. 1999. Non-timber forest products in Ontario. Ont. Min. Nat. Res., Ont. For. Res. Inst., For. Res. Info. Pap. No. 145, Sault 
Ste. Marie, ON. 64 p.

Newton, M., M.L. McCormack Jr., R.L. Sajdak and J.D. Walstad. 1987. In J.D. Walstad and P.J. Kuch. Forest Vegetation Management for Conifer Production. pp. 77-103. John Wiley, New York, NY.

Newton, M., E.C. Cole, M.L. McCormack Jr. and D.E. White. 1992. Young spruce-fir forests released by herbicides II. Conifer response to residual hardwoods and overstocking. Northern Journal of Applied Forestry 9(4): 130-135.

Nyland, R.D. 1996. Silviculture: Concepts and Applications. McGraw-Hill, New York, NY.

Oliver, C.D. 1999. The future of the forest management industry: Highly mechanized plantations and reserves or a knowledge-intensive integrated approach? For. Chron. 75(2): 229-245.

Ontario Ministry of Natural Resources (OMNR). 1999a. Ontario's Living Legacy land use strategy. Queen's Printer for Ontario, Toronto, ON. $136 \mathrm{p}$.

Ontario Ministry of Natural Resources (OMNR). 1999b. Ontario Forest Accord - A foundation for progress. Queen's Printer for Ontario, Toronto, ON. 136 p.

Perry, D.A. 1998. The scientific basis of forestry. Annu. Rev. Ecol. Syst. 29: 435-466.

Pugel, A.D., E.W. Price and C.Y. Hse. 1990a. Composites from southern pine juvenile wood. Part 1. Panel fabrication and initial properties. For. Prod. J. 40(1): 29-33.

Pugel, A.D., E.W. Price and C.Y. Hse. 1990b. Composites from southern pine juvenile wood. Part 2. Durability and dimensional stability. For. Prod. J. 40(3): 57-61.

Puettmann, K.J. and A.R. Ek. 1999. Status and trends of silvicultural practices in Minnesota. Northern Journal of Applied Forestry. 16(4): 203-210.

Reed, F.L.C. (and Associates). 1978. Forest Management in Canada. Vol. 1. Can. Dep. Environ., For. Manage. Inst., Info. Rept. FMR-X-102, Ottawa, ON. 155 p.

Rowe, J.S. 1992. Prolog/Avant-propos. For. Chron. 68(1): 22-24. Society of American Foresters (SAF). 1983. Terminology of forest science technology practice and products. Society of American Foresters, Washington, DC. 370 p.

Sedjo, R.A. 1999. The potential of high-yield plantation forestry for meeting timber needs - Recent performance, future potentials, and environmental implications. New Forests 17: 339-359.

Sedjo, R.A. and D. Botkin. 1997. Using forest plantations to spare natural forests. Environment 39(10): 15-20, 30.

Sedjo, R.A., A. Goetzl and S.O. Moffat. 1998. Sustainability of temperate forests. Resources for the Future, Washington, DC. 102 p. Seymour, R.S. and M.L. McCormack Jr. 1989. Having our forest and harvesting it too: The role of intensive silviculture in resolving forest land use conflicts. In R.D. Briggs et al. (eds.). Forest Wildlife Management in New England - What can we afford? pp. 207-213. Maine Agri. Exp. Sta. Misc. Rep. 336. Univ. Maine, Orono, ME. Seymour, R.S. and M.L. Hunter Jr. 1992. New forestry in eastern spruce-fir forests: Principles and applications to Maine. Misc, Pub. 716. Maine Agri. Exp. Sta., Univ. of Maine, Orono, ME. 32 p.

Shepard, R.K. and J.E. Shottafer. 1990. Effects of early release on specific gravity and wood yield of black spruce. For. Prod. J. 40(1): 18-20.

Shepard, R.K., J.E. Shottafer and W.C. Bragg. 1991. Stand age and density effects on volume and specific gravity of black spruce. Tech. Bull 139. Maine Agric. Exp. Stn., Univ. Maine, Orono, ME.
Sherry, E.E. and C.J. Johnson. 1999. The forgotten forest: Revisiting the forestland allocation strategy. For. Chron. 75(6): 919-927. Sims, R. A., I. G. W. Corns and K. Klinka. 1996. Introduction global to local: ecological land classification. In R.A. Sims, I.G.W. Corns and K. Klinka. (eds.). Global to local: Ecological land classification. pp. 1-10. Kluwer Academic, London, UK.

Smith, D. M., B.C. Larson, M.J. Kelty and P.M.S. Ashton. 1997. The Practice of Silviculture: Applied Forest Ecology. John Wiley, New York, NY.

Stewart, R.E., L.L. Gross and B.H. Honkala. 1984. Effects of competing vegetation on forest trees: a bibliography with abstracts. Gen. Tech. Rep. WO-43, USDA Forest Service, Washington, DC. $260 \mathrm{p}$.

Spinazze, M.C. and S. Kant.1999. Market potential for certified forest (wood) products in Ontario, Canada. For. Chron. 75(1): 39-47. Sutton, W.R.J. 1999. The need for planted forests and the example of radiata pine. New Forests 17: 95-109.

Taylor, N.W. (Chair). 1999. Competing realities: The boreal forest at risk. Report of the sub-committee on boreal forest of the standing Senate committee on agriculture and forestry. Ottawa, ON.

Theophile, K. 1995. The forest as a business: is ecotourism the answer. J. For. 93(3): 25-27.

Turnbull, J. W. 1999. Eucalypt plantations. New Forests 17: 37-52. Wagner, R.G., L.J. Buse, R.A. Lautenschlager, F.W. Bell, C. Hollstedt, S. Strobl, A. Morneault, W. Lewis and M.T. Ter-Mikaelian. 1995. Vegetation Management Alternatives Program 1994-95 Annual Report. Ont. Min. Nat. Res., Ont. For. Res. Inst., Sault Ste. Marie, ON. 99 p.

Wagner, R.G., J. Flynn and R. Gregory. 1998. Public perceptions of risk and acceptability of forest vegetation management alternatives in Ontario. For. Chron. 74(5): 720-727.

Wagner, R.G. and D.G. Thompson (comp.). 1998. Third international conference on forest vegetation management: Popular summaries. Ont. Min. Nat. Resour., Ont. For. Res. Inst., For. Info. Pap. No. 141. $508 \mathrm{p}$.

Wagner, R.G., G.H. Mohammed and T.L. Noland. 1999. Critical period of interspecific competition for northern conifers associated with herbaceous vegetation. Can. J. For. Res. 29: 890-897.

Walstad, J.D. and P.J. Kuch. 1987. Forest vegetation management for conifer production. John Wiley, New York, NY. 523 p.

Walstad, J.D., M. Newton and D.H. Gjerstad. 1987. Overview of vegetation management alternatives. In J.D. Walstad and P.J. Kuch (eds.). Forest vegetation management for conifer production. pp.157-200. John Wiley, New York, NY.

Wernick, I.K., P.E. Waggoner and J.H. Ausubel. 1998. Searching for leverage to conserve forests: The industrial ecology of wood products in the United States. J. Indust. Ecol. 1(3): 125-145.

World Commission on Environment and Development (WCED). 1987. Our common future. Oxford University Press, Oxford, UK. 400 p.

Widner, R.A. (ed.). 1968. Forests and Forestry in the American States. National Association of State Foresters. Washington, DC. 594 p. Wilson, B. and L. Arthur. 1998. New Zealand. In B. Wilson, G.C. van Kooten, I. Vertinsky and L. Arthur (eds.). Forest Policy: International Case Studies. pp. 129-153. CABI, Oxford, UK. 